\title{
Management and Outcome of Chylous Ascites in Children: A CARE compliant Case Series
}

\author{
Magd A. Kotbํ, Dalia S. Mosallam1, Heba Amin Ragab1, Hend Abd El Baky1*, \\ Ahmed El Hatw ${ }^{1}$, Alaa F. Hamza', Hesham Abd El Kader², Gamal El Tagy ${ }^{3}$, \\ Haytham Esmat ${ }^{3}$, Sherif M. Shehata ${ }^{4}$, Nahla I. Sabry ${ }^{1}$ \\ 1 Department of Pediatrics, Faculty of Medicine, Cairo University, Egypt; \\ magdkotb@kasralainy.edu.eg, daliamosalam@hotmail.com,drhebaaminragab@gmail.com, \\ hend.elhossainy@gmail.com, ahmed.m.abdelmutae@kasralainy.edu.eg, nahla595@gmail.com \\ 2 Department of Pediatric Surgery, Faculty of Medicine, Ain Shams University, Egypt; \\ shamza@idsc.net.eg, heshamabdelkader@yahoo.com \\ ${ }^{3}$ Department of Pediatric Surgery, Faculty of Medicine, Cairo University, Egypt; geltagy@gmail.com, \\ haythamesmate@yahoo.com \\ 4 Department of Pediatric Surgery, Faculty of Medicine, Tanta University, Egypt; \\ sherifshehata2001@yahoo.com \\ * Correspondence: hend.elhossainy@gmail.com, hend.elhossainy@cu.edu.eg \\ Received: 26/5/2020; Accepted: 15/10/2020; Published online: 25/12/2020.
}

\begin{abstract}
:
Background: Chylous ascites (CA) is accumulation of lipid rich lymph in peritoneal cavity. CA is rare among children. In pediatric age, causes of CA varies according to the age group, leading primary causes include congenital malformation of lymphatic system, and less likely lymphatic obstruction such as intestinal malrotation, gastroschisis, infections or trauma of thoracic duct. Aim of the work: We aim to report outcome of congenital CA in a pediatric cohort.

Material and Methods: Retrospective analysis of data of 4 children (4 boys) who presented by CA to New Children Hospital, Cairo University during 2010- 2018.

Results: Duration of follow up of the boys was $6.5,5,2.5$, and 0.25 years respectively. All presented by abdominal distention and diagnostic tapping of ascitic fluid revealed triglyceride level more than $200 \mathrm{mg} \%$, protein more than $2 \mathrm{~g} \%$ and/or a cell count greater than $500 / \mathrm{cmm}$ with a predominance of lymphocytes (> $80 \%)$. Lymphatic scintigraphy in 3 of them revealed no abnormality in lymph drainage. The course of disease was punctuated by chylothorax, and chylous hydrocoele in all 4 cases. All 4 did not respond to medium chain triglyceride based diet. One child underwent peritenovenous shunt, and the other 3 responded to somatostatin analogue octreotide SC injections during hospital stay and maintenance therapy. Last child was lost to follow up. All other 3 are fine with minimal complications and living with mild peritoneal ascites. Conclusion: Somatostatin analogue therapy provided well-tolerated non-invasive control of congenital CA in our studied pediatric cohort. Surgical intervention should be restricted to those with underlying surgical cause and in those failing to respond to medical treatment.
\end{abstract}

Level of Evidence of Study: IIB. (1)

Keywords: Primary chylous ascites, peritoneo-venous shunt; pediatric neonate; somatostatin; Medium chain triglycerides based diet MCTs; Lymphatic scintigraphy.

Abbreviations: CA: chylous ascites; MCTs: medium chain triglycerides; PCR: polymerase chain reaction; SC: subcutaneous.

\section{Introduction}

Chylous Ascites (CA) is a rare disease resulting from leakage of lipid rich fluid inside the peritoneal cavity. The cause of CA in pediatric population varies according to the age group. Causes of CA in neonates include congenital malformation and causes of lymphatic obstruction such as intestinal malrotation, gastroschisis and traumatic injury of thoracic duct. In older children, lymphatic obstruction secondary to surgery or infections as tuberculosis are the commonest etiologies. Although neoplasms or trauma are more common in adult population they are considered rare causes in CA in pediatric age. Patients most commonly present with 
abdominal distention, hydrocoele, chylothorax or peritonitis. Also, pain could be present. Less common presentations include vague symptoms such as nausea, vomiting, fever, night sweats, diarrhea and in cirrhotic patients with liver cell failure stigmata may be present (2-5). There is lack of consensus on the optimum management option for CA. Among the available alternatives; nutritional, pharmacological and surgical options present themselves. Treating the underlying etiology in most cases results in resolution of symptoms $(4,6)$. Nutritional support is a used measure in most of cases which involves a high protein diet and low-fat diet including medium chain triglycerides (MCTs) to reduce chyle formation. Total parental nutrition can be resorted to if there is no improvement of symptoms. Medical therapy include somatostatin or its analogue octreotide (7). Orlistat is advised among adults as it reversibly inhibits pancreatic lipase and fatty acid synthetase thus reducing the absorption of triglycerides. In addition, it inhibits glucagon and splanchnic peptides reducing the portal pressure $(8,9)$. Invasive interventions include minimally invasive endolymphatic embolization (10), surgical peritoneo-venous shunt placement (6) and treatment of causes as removal of associated cyst, subtotal omentectomy (4) and sealing lymphatic tear by fibrin glue (11). We present our experience with 4 neonates and children with CA during 2010-2018.

\section{Subjects and Methods}

This is a retrospective observational study. Data were extracted by comprehensive chart review, including demographics, clinical presentation, imaging studies, response to different treatments (MCTs based-diet, surgical intervention and SC somatostatin analogue) and complications of different therapies were described. Outcome was defined in terms of survival, growth (weight and height), response to therapy and presence of ascites/ hydrocele at last follow up.

\section{Participants}

In this retrospective observational study, we describe a cohort of 4 children who presented to the Hepatology Clinic New Children Pediatric Hospital, Cairo University by CA during 20102018. Parental approval was not applicable to this retrospective observational noninterventional cohort study. The study complies with Declaration of Helsinki - Ethical Principles for Medical Research Involving Human Subjects. It is as CARE compliant study (12). The children were suspected to have CA based upon clinical signs of abdominal distension, ascites, typical ascitic fluid findings of triglyceride level more than $200 \mathrm{mg} \%$, protein more than $2 \mathrm{~g} \%$ and/or a cell count greater than $500 / \mathrm{cmm}$ with a predominance of lymphocytes $(>80 \%)(8)$ [figure1]. Other investigations were done to search for underlying etiology including abdominal sonar, CT abdomen and lymphatic scintigraphy.

\section{Statistical Analysis}

Statistical Package for Social Sciences version 15 (SPSS, Chicago, Ill) was used to conduct statistical analysis in this study. Simple frequency, cross-tabulation and descriptive analysis were employed.

\section{Results}

The age of the 4 children at presentation was 15 days, 6 months, 13 months and 36 months, and all presented by massive ascites causing respiratory distress and associated with failure to thrive. All were boys, and 2 were products of consanguineous marriages. There were no similar conditions in the family. None responded to MCTs based diets. Abdominal sonar and CT abdomen were unrevealing apart from massive ascites. Ascitic tapping was diagnostic in all children (Figure 1). Lymphangiogram done in 3 children did not reveal tears or leaks or other abnormality (9). Child 1 needed frequent tapping and underwent peritoneovenous shunt placement. It was obstructed a year later and the child suffered from massive CA and hydrothorax that responded to abdominal parenthesis and initial 24 hours IV somatostatin analogue octreotide (0.3-4 $\mathrm{mcg} / \mathrm{kg} / \mathrm{hr}$ ) followed by SC $2 \mathrm{mcg} / \mathrm{kg}$ twice per week. 
Table 1. Chylous ascites clinical presentation in 4 neonates and infants who presented to Hepatology Clinic, New Children Hospital, Cairo University.

\begin{tabular}{|c|c|c|c|c|}
\hline & Child 1 & Child 2 & Child 3 & Child 4 \\
\hline Year of presentation & 2010 & 2014 & 2017 & 2017 \\
\hline Gender & Boy & Boy & Boy & Boy \\
\hline Age at onset in months & 6 & 36 & 13 & 0.5 \\
\hline Consanguinity & negative & negative & positive & positive \\
\hline Major Complications & $\begin{array}{l}\text { Chylothorax, } \\
\text { Massive ascites, } \\
\text { Repeated ascitic } \\
\text { tap, Hydroceole, } \\
\text { Failure to thrive }\end{array}$ & $\begin{array}{l}\text { Chylothorax, } \\
\text { Massive } \\
\text { ascites, } \\
\text { Repeated } \\
\text { ascitic tap, } \\
\text { Hydroceole, } \\
\text { Failure to } \\
\text { thrive, } \\
\text { Difficulty in } \\
\text { walking and } \\
\text { sitting }\end{array}$ & $\begin{array}{l}\text { Chylothorax, } \\
\text { Massive } \\
\text { ascites, } \\
\text { Repeated } \\
\text { ascitic tap, } \\
\text { Constipation, } \\
\text { Hydroceole, } \\
\text { Failure to } \\
\text { thrive }\end{array}$ & $\begin{array}{l}\text { Massive ascites, } \\
\text { Hydrocoele, } \\
\text { Failure to thrive }\end{array}$ \\
\hline Sonar & $\begin{array}{l}\text { No abnormality } \\
\text { apart from } \\
\text { ascites }\end{array}$ & $\begin{array}{l}\text { No abnormality } \\
\text { apart from } \\
\text { ascites }\end{array}$ & $\begin{array}{l}\text { No abnormality } \\
\text { apart from } \\
\text { ascites }\end{array}$ & $\begin{array}{l}\text { No abnormality } \\
\text { apart from } \\
\text { ascites }\end{array}$ \\
\hline Lymphangiogram & Normal & Normal & Normal & Not done \\
\hline CT Abdomen & $\begin{array}{l}\text { No abnormality } \\
\text { apart from } \\
\text { ascites }\end{array}$ & $\begin{array}{c}\text { No abnormality } \\
\text { apart from } \\
\text { ascites }\end{array}$ & $\begin{array}{l}\text { No abnormality } \\
\text { apart from } \\
\text { ascites }\end{array}$ & $\begin{array}{l}\text { No abnormality } \\
\text { apart from } \\
\text { ascites }\end{array}$ \\
\hline
\end{tabular}

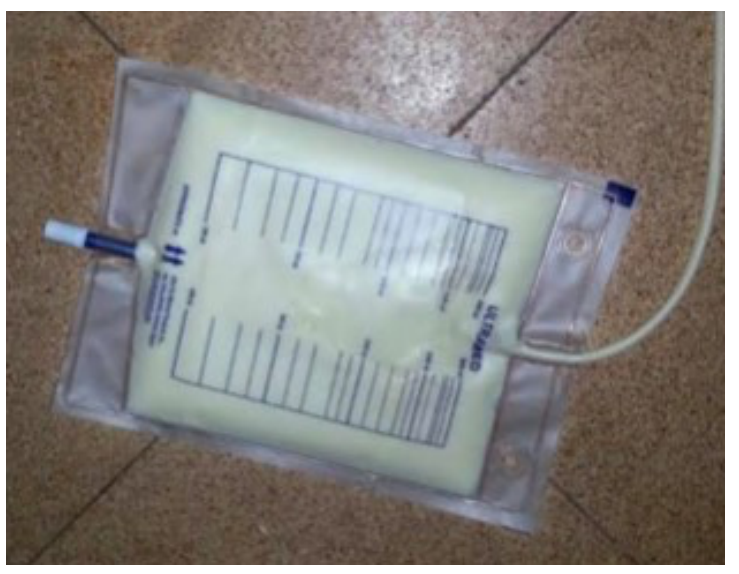

Figure 1. Tapped chylous ascites typical appearance.

After 2 weeks, his condition was controlled with a mild amount of ascites that did not need maintenance somatostatin thereafter. The other 3 boys received hospital IV and SC somatostain, but ascites recurred massively in two which necessitated home biweekly SC doses of somatostatin that needed maintenance dose adjustment in only one child, while the other was off medications 4 months later without recurrence. Tables 1 and 2 demonstrate the clinical characteristics and outcomes of the 4 children. 
Table 2. Chylous ascites outcome in 4 neonates and infants who presented to Hepatology Clinic, New Children Hospital, Cairo University.

\begin{tabular}{|c|c|c|c|c|}
\hline & Child 1 & Child 2 & Child 3 & Child 4 \\
\hline MCTs based Diet & No response & No response & No Response & No Response \\
\hline Surgical Intervention & $\begin{array}{c}\text { Peritoneal } \\
\text { Shunt } \\
\text { Placement at } 18 \\
\text { months }\end{array}$ & $\begin{array}{c}\text { No } \\
\text { intervention }\end{array}$ & $\begin{array}{c}\text { Hydrocele } \\
\text { Surgical repair }\end{array}$ & No intervention \\
\hline SC Somatostatin Analogue & $\begin{array}{c}\text { SC } \\
\text { somatostatin } \\
\text { analogue was } \\
\text { not initiated } \\
\text { prior to shunt } \\
\text { placement } \\
\text { It was used for } \\
2 \text { weeks during } \\
\text { hospital stay at } \\
\text { age of } 2.5 \text { years } \\
\text { after which } \\
\text { child had mild } \\
\text { ascites that did } \\
\text { not necessitate } \\
\text { management }\end{array}$ & $\begin{array}{c}\text { Used after } \\
\text { initial tapping } \\
\text { and } \\
\text { maintained } \\
\text { biweekly since } \\
\text { diagnosis } \\
\text { Once stopped } \\
\text { moderate } \\
\text { ascites recurs. } \\
\text { Maintained } \\
\text { biweekly to } \\
\text { control ascites } \\
\text { for } 12 \text { months }\end{array}$ & $\begin{array}{c}\text { Used after } \\
\text { initial tapping } \\
\text { and } \\
\text { maintained } \\
\text { biweekly for } 4 \\
\text { months } \\
\text { Ascites did not } \\
\text { recur }\end{array}$ & $\begin{array}{l}\text { Controlled } \\
\text { ascites when } \\
\text { used after } \\
\text { ascitic tapping }\end{array}$ \\
\hline Abdominal binder & Not tolerated & Not tolerated & Tolerated & Not tolerated \\
\hline Complications Of Therapy & $\begin{array}{c}\text { Shunt } \\
\text { obstruction } 1 \\
\text { year later, with } \\
\text { development of } \\
\text { right } \\
\text { chylothorax. } \\
\text { Condition } \\
\text { arrested after } \\
\text { tapping and } \\
\text { sandostatin } \\
\text { analogue } \\
\text { treatment } \\
\text { during hospital } \\
\text { stay } \\
\text { Shunt was not } \\
\text { removed. }\end{array}$ & None & None & None \\
\hline Follow up duration in years & 6.5 & 5 & 2.5 & 0.25 \\
\hline Outcome & $\begin{array}{l}\text { Alive and well } \\
\text { till age of } 6 \text { y } \\
\text { after which he } \\
\text { dropped out. } \\
\text { Attained height } \\
\text { and weight, } \\
\text { Mild ascites } \\
\text { Spontaneous } \\
\text { resolution of } \\
\text { hydrocoele } \\
\text { Child awaits } \\
\text { surgical } \\
\text { removal of } \\
\text { shunt. }\end{array}$ & $\begin{array}{l}\text { Alive and well. } \\
\text { Aged 8.5y at } \\
\text { last follow up. } \\
\text { Attained } \\
\text { height and } \\
\text { weight, } \\
\text { Mild ascites } \\
\text { Spontaneous } \\
\text { resolution of } \\
\text { hydrocoele }\end{array}$ & $\begin{array}{l}\text { Alive and well. } \\
\text { Aged } 4 \text { y at last } \\
\text { follow up } \\
\text { Attained } \\
\text { height and } \\
\text { weight, } \\
\text { No ascites }\end{array}$ & $\begin{array}{l}\text { Dropped out } \\
\text { after } 3 \text { month of } \\
\text { follow up. } \\
\text { Ascites was } \\
\text { controlled } \\
\text { during last } \\
\text { follow up }\end{array}$ \\
\hline
\end{tabular}




\section{Discussion}

CA results from primary congenital lacteal failure of transport of chyle, or secondary to trauma or obstruction of lacteal system. Congenital CA is a diagnosis of exclusion and suggested by earlier age at presentation (13), yet our case series suggests that the age at presentation of CA can be neonatal, infantile and juvenile, and that the earlier congenital variety might present as isolated CA without associated congenital structural abnormalities, trauma, malignancy and other inflammatory processes. Hence, it seems that exhausting financial means to investigate associations of CA might be reserved to those with other clinical suspicion, those unresponsive to therapy, and older children (9).

Congenital $\mathrm{CA}$ is a rare disease and is not a lifelong ailment, hence once diagnosis is established there is no rush for surgical management and shunt placement. The lacteal malabsorption seems to be a functional problem that improves by time, that might be related to some immaturity (14), or dysfunction as there are many factors and circulating mediators that modulate lymphatic contractile activity and thus lymph flow (15). Attaining lacteal absorptive maturity might explain why our child who underwent shunt placement had complete resolution of symptoms despite the obstruction of shunt.

Abdominal paracentesis is vital for establishment of diagnosis of CA. It has been the most valuable time-honored diagnostic procedure (9). The gross appearance of chylous ascitic fluid is peculiar (milky white fluid) and is a bed side conclusive procedure, along with the lab cytology (cell count, gram stain and culture) and chemical analysis (concentrations of glucose, albumin, total protein, amylase, lactate dehydrogenase and triglyceride level). If tuberculosis is suspected; acid-fast bacilli smear, culture, adenosine deaminase and PCR is recommended (16).

Imaging of lymphatic system is essential for diagnosis and management of congenital CA (17). Where lympho-scintigraphy is of choice especially in the younger neonates, yet lymphangiography could be resorted to in complicated, refractory to therapy cases (18) because of the technical difficulties in the very small neonates, and other side effects. The youngest of our four studied cases was not subjected to imaging of lymphatic system as he responded to taping and short course of subcutaneous somatostatin analogue with no further suspicion of underlying structural anatomic abnormality. Hence, our work supports performing imaging of lymphatic system only for those with no response to medical management by somatostatin analogue.

MCTs were not effective in controlling or reducing the ascites in our case series. MCTs are water soluble, and do not require bile or pancreatic enzymes for absorption, as they passively diffuse through intestinal brash border into the portal system bound to albumin. MCTs reach mitochondria for $\beta$-oxidation independent of carnitine acyltransferase system (19). MCTs based diet is praised as the successful conservative management of CA due to chylous fistulas that developed after surgical neck dissections or another surgical pancreatic resection (with or without abdominal paracentesis) (20-22).

In the current study, there was no significant improvement associated with MCTs based diet which may be explained by 1 - very small sample size of studied group, 2- CA in our studied group was not due to chyle leak following surgical procedure, contrary to other reports where the cause was surgical leak, hence MCTs might prove to be successful only in chyle surgical leaks, 3- chyle leaks are self-limiting by nature, once healing of surgical leak occurs and MCTs role is a mere confounder and not effective, 4- congenital CA "leaky lymphatics" might be caused by delayed maturation of the lacteals (14), hence MCTs would reduce new chyle production but would not enhance the absorption of the already present CA.

As somatostatin is known to reduce portal and splanchnic blood flow (23), we regarded ischemia of intestine and necrotizing enterocolitis as real possible complications, hence, we restricted IV somatostatin analogue octreotide to a maximum of 24 hours $(0.3-4 \mathrm{mcg} / \mathrm{kg} / \mathrm{hr})$ after initial abdominal paracentesis followed by SC $2 \mathrm{mcg} / \mathrm{kg}$ twice per week. Somatostatin analogue was effective and safe in management of congenital CA in our studied group and we did not come across complications as necrotizing enterocolitis or transient hypothyroidism (24). Biweekly home maintenance of SC somatostatin was effective in two children, one resolved in four months and the other has been controlled for 12 months on the biweekly regimen, but once stopped ascites re-accumulates. 
We report that surgical shunt placement obstruction in congenital CA is a serious complication, and it is unfortunately reported to be the commonest complication along with other common complications that require multiple shunt revisions as infection pseudocyst and bowel perforation (9). Hence shunt placement, should be contemplated in established congenital CA only after medical management by biweekly SC somatostatin fails.

The current study is not free of limitations. The retrospective study design and the limited number of patients makes it difficult to discern the efficacy of MCTs- based diet and limits generalization of recommendations. The effect of gender was not explored as no female patients were included in our study.

\section{Conclusions}

Primary congenital CA could present in children until three years of age. Somatostatin analogue therapy provided well-tolerated non-invasive control of congenital CA in our studied pediatric cohort. MCTs based diet was not effective in control of congenital CA in our studied pediatric cohort. Surgical shunt placement should be contemplated in established congenital CA only after medical management by biweekly SC somatostatin fails.

\section{Author Contributions:}

All authors searched medical literature, databases, conceptualized, conducted the case review and reviewed the final manuscript. All authors have read and agreed to the published version of the manuscript.

\section{FUNDING}

Authors declare there was no extramural funding provided for this study.

\section{CONFLICT OF INTEREST}

The authors declare no conflict of interest in connection with the reported study. Authors declare veracity of information.

\section{References}

1. S. Tenny, M. Varacallo, Evidence Based Medicine. (StatPearls Publishing; Treasure Island (FL), 2020; https://www.ncbi.nlm.nih.gov/books/NBK470182/).

2. J. Romańska-Kita, M. K. Borszewska-Kornacka, A. Dobrzańska, I. Rudzińska, J. CzechKowalska, T. Wawrzoniak, Congenital chylous ascites. Pol. J. Radiol. 76, 58-61 (2011).

3. C. R. Zalles-Vidal, A. Peñarrieta-Daher, D. Ibarra-Rios, E. Fernandez-Portilla, E. BrachoBlachet, Chylous Ascites in a Newborn with Gastroschisis. Case Report. J. Neonatal Surg. 6, 16 (2017).

4. A. Albaghdady, K. M. El-Asmar, M. Moussa, S. Abdelhay, Surgical management of congenital chylous ascites: Ann. Pediatr. Surg. 14, 56-59 (2018).

5. J. T. Salsamendi, F. J. Gortes, P. P. Mohan, J. Fan, G. Narayanan, Transjugular intrahepatic portosystemic shunt for chylous ascites in a patient with recurrent cirrhosis following liver transplantation. Radiol. Case Rep. 12, 84-86 (2017).

6. H. Yarmohammadi, L. A. Brody, J. P. Erinjeri, A. M. Covey, F. E. Boas, E. Ziv, M. Maybody, A. J. Gonzalez-Aguirre, K. T. Brown, J. Sheinfeld, G. I. Getrajdman, Therapeutic Application of Percutaneous Peritoneovenous (Denver) Shunt in Treating Chylous Ascites in Cancer Patients. J. Vasc. Interv. Radiol. JVIR. 27, 665-673 (2016).

7. Q. Huang, Z.-W. Jiang, J. Jiang, N. Li, J.-S. Li, Chylous ascites: treated with total parenteral nutrition and somatostatin. World J. Gastroenterol. 10, 2588-2591 (2004).

8. J. Chen, R. K. Lin, T. Hassanein, Use of orlistat (xenical) to treat chylous ascites. J. Clin. Gastroenterol. 39, 831-833 (2005).

9. R. Bhardwaj, H. Vaziri, A. Gautam, E. Ballesteros, D. Karimeddini, G. Y. Wu, Chylous Ascites: A Review of Pathogenesis, Diagnosis and Treatment. J. Clin. Transl. Hepatol. 6, 105-113 (2018).

10. R. N. Srinivasa, J. F. B. Chick, J. J. Gemmete, A. N. Hage, R. N. Srinivasa, Endolymphatic Interventions for the Treatment of Chylothorax and Chylous Ascites in Neonates: Technical and Clinical Success and Complications. Ann. Vasc. Surg. 50, 269-274 (2018). 
11. B. D. Carr, C. N. Grant, R. E. Overman, S. K. Gadepalli, J. D. Geiger, Retroperitoneal exploration with Vicryl mesh and fibrin tissue sealant for refractory chylous ascites. $J$. Pediatr. Surg. 54, 604-607 (2019).

12. EQUATOR Centre UK, Equator network: Enhancing the quality and transparency of health research, (available at https://www.equator-network.org/reporting-guidelines/).

13. N. L. Browse, N. M. Wilson, F. Russo, H. al-Hassan, D. R. Allen, Aetiology and treatment of chylous ascites. Br. J. Surg. 79, 1145-1150 (1992).

14. J. K. Chye, C. T. Lim, M. Van der Heuvel, Neonatal chylous ascites--report of three cases and review of the literature. Pediatr. Surg. Int. 12, 296-298 (1997).

15. A. Mukherjee, J. Hooks, Z. Nepiyushchikh, J. B. Dixon, Entrainment of Lymphatic Contraction to Oscillatory Flow. Sci. Rep. 9, 5840 (2019).

16. T. Almakdisi, S. Massoud, G. Makdisi, Lymphomas and chylous ascites: review of the literature. The Oncologist. 10, 632-635 (2005).

17. V. Mouravas, O. Dede, H. Hatziioannidis, I. Spyridakis, A. Filippopoulos, Diagnosis and management of congenital neonatal chylous ascites. Hippokratia. 16, 175-180 (2012).

18. S. J. Fishman, P. E. Burrows, J. Upton, W. H. Hendren, Life-threatening anomalies of the thoracic duct: anatomic delineation dictates management. J. Pediatr. Surg. 36, 1269-1272 (2001).

19. B. N. L. Shah, The Use of Medium-Chain Triglycerides in Gastrointestinal Disorders. Pract. Gastroenterol. 16, 20-28 (2017).

20. R. Purkait, A. Saha, I. Tripathy, B. Roy, Congenital chylous ascites treated successfully with MCTs-Based formula and octreotide. J. Indian Assoc. Pediatr. Surg. 19, 175-177 (2014).

21. I. C. Martin, L. H. Marinho, A. E. Brown, D. McRobbie, Medium chain triglycerides in the management of chylous fistulae following neck dissection. Br. J. Oral Maxillofac. Surg. 31, 236-238 (1993).

22. M. Abu Hilal, D. M. Layfield, F. Di Fabio, I. Arregui-Fresneda, I. G. Panagiotopoulou, T. H. Armstrong, N. W. Pearce, C. D. Johnson, Postoperative chyle leak after major pancreatic resections in patients who receive enteral feed: risk factors and management options. World J. Surg. 37, 2918-2926 (2013).

23. J.-Y. Zhu, X.-S. Leng, D. Wang, R.-Y. Du, Effects of somatostatin on splanchnic hemodynamics in cirrhotic patients with portal hypertension. World J. Gastroenterol. 6, 143-144 (2000).

24. A. Das, P. S. Shah, Octreotide for the treatment of chylothorax in neonates. Cochrane Database Syst. Rev., CD006388 (2010). 